DOI 10.31558/2519-2949.2020.1.19

УДК $355.4+007$

ORCID ID: https://orcid.org/0000-0002-0326-0823

Семенюк Ю. В., Воєнно-дипломатична академія імені Свгенія Березняка

ORCID ID: https://orcid.org/0000-0001-5978-8101

Голинський І. М., Воєнно-дипломатична академія імені Евгенія Березняка

\title{
ВИОКРЕМЛЕННЯ ТА ОБГРУНТУВАННЯ ОСНОВНИХ СКЛАДОВИХ СУСПІЛЬНО-ПОЛІТИЧНОЇ ОБСТАНОВКИ
}

\begin{abstract}
Досліджуються основні складові суспільно-політичної обстановки та ї̈ елементний склад: зовнішньополітичний курс держави; внутрішньополітична обстановка в регіоні чи державі; політичне (воєнно-політичне) керівництво; оцінка політичних норм; аналіз політичної культури суспільства; стан економіки регіону чи держави; стан збройних сил (в тому числі аналіз можливостей щьодо ведення гібридної війни); соиіально-психологічна атмосфера у суспільстві; етноконфесійна ситуація в регіоні чи державі; демографічна ситуачія в регіоні чи державі; географічне розташування; екологічна обстановка в регіоні чи державі; криміногенна ситуачія в регіоні чи державі. Визначено структурні елементи суспільно-політичної обстановки, до яких відносяться: суб' 'єкти суспільно-політичного процесу; соџіально-політичні інтереси та цілі; реальні соціально-політичні подї, процеси та явища. Вплив таких чинників на суспільно-політичну обстановку буде визначати ї̈ рівень, а саме: звичайна, загострена, кризова, надзвичайна.

Відзначено, що головною метою оцінювання суспільно-політичної обстановки є відображення ситуації та визначення факторів, умов, подій, явищ, які необхідно постійно аналізувати для подальшого впливу на суспільно-політичні процеси. Показано, що всебічний аналіз, оцінювання суспільно-політичної обстановки полягає у визначенні факторів розвитку та взаємовідносин суб 'єктів суспільно-політичного процесу, які безпосередньо чи опосередковано впливають на суспільно-політичну обстановку у державі чи окремому регіоні. Саме це надає керівництву держави можливість діяти щฺодо стабілізаџії, або дестабілізаџії ситуаџї̈, як на міжнародній арені, так і всередині держави.
\end{abstract}

Ключові слова: суспільно-політична обстановка, елементний склад, суспільно-політичні проиеси, оцінювання, прогнозування, фактори, умови, події, явища.

Загальноприйнятою методологією, що використовується при дослідженні складних соціальноекономічних та технічних систем [1], є системний аналіз [2, 3]. Враховуючи особливості предметної галузі при проведенні аналізу та оцінки суспільно-політичної обстановки, як методологічну основу слід використовувати системний підхід [4], який полягає у застосуванні сукупності методологічних принципів і теоретичних положень [5], що дають змогу розглядати кожний елемент суспільнополітичної обстановки у його зв'язку і взаємодії з іншими елементами; простежувати зміни, що відбуваються у суспільно-політичної обстановки в результаті зміни іiі окремих ланок; вивчати специфічні емерджентні властивості суспільно-політичної обстановки; робити обгрунтовані висновки про закономірності її розвитку [6].

При проведенні дослідження суспільно-політичної обстановки також використовувалися таки загальні та спеціальні методи та прийоми пізнання, як факторний аналіз [7], експертні методи [8-10], теорія прийняття рішень [11, 12], прогнозування [13], передбачення [14], порівняння, узагальнення, аналогія, експерименти тощо.

Грунтуючись на основних положеннях і методах системного аналізу визначено, що елементний склад суспільно-політичної обстановки повинен містити відомості про відповідну сферу, процес держави чи окремого регіону, що вивчається. Основними елементним складом суспільно-політичної обстановки є не тільки пасивне відображення інформації про події, визначення того чи іншого процесу, а й тенденції розвитку ситуації, реальні можливості політичних сил та інститутів, орієнтації, можливості управлінської еліти тощо. Таким чином, з метою системного оцінювання 
суспільно-політичної обстановки у певній державі, чи регіоні аналізується наступний елементний склад суспільно-політичної обстановки: зовнішньополітичний курс держави; внутрішньополітична обстановка в регіоні чи держави; політичне (воєнно-політичне) керівництво; оцінка політичних норм; аналіз політичної культури суспільства; стан економіки регіону чи держави; стан збройних сил (в тому числі аналіз можливостей щодо ведення гібридної війни); соціально-психологічна атмосфера у суспільстві; етноконфесійна ситуація в регіоні чи державі; демографічна ситуація в регіоні чи державі; географічне розташування; екологічна обстановка в регіоні чи державі; криміногенна ситуація в регіоні чи державі.

При аналізі суспільно-політичної обстановки, крім цього елементного складу суспільнополітичного життя в регіоні чи державі, що вивчається, можуть бути використані й інші додаткові фактори. Аналіз змісту кожного складника, механізм їх впливу на суспільно-політичні процеси, а також їх сукупність може бути покладено в основу факторного методу оцінки суспільнополітичної обстановки в регіоні чи державі. При визначенні складників велику роль в об'єктивній оцінці отриманих результатів відіграє підбір цих показників, що найбільш повно (кількісно та якісно) характеризують кожний фактор. До основних вимог слід віднести: врахування якості складника, що розглядається; найбільш повна кількісна оцінка; можливість обрахування складника з урахуванням всієї інформації та професійні здібності того, хто буде здійснювати оцінку будь-якого складника.

При оцінці зовнішньополітичного курсу держави необхідно враховувати насамперед стратегічний підхід держави до відносин з іноземними державами, співпраці з міжнародними організаціями, просування власних національних інтересів та захисту своїх громадян за кордоном. Отже до основних факторів зовнішньополітичного курсу держави відносять: місце і роль держави в міжнародному співтоваристві та міжрегіональній співпраці; підготовка та укладання двосторонніх і багатосторонніх договорів та угод; ступінь прагнення до інтеграції та участь держави в політичних, військових та економічних союзах і блоках; наявність та глибина міждержавних суперечностей (протиріч); взаємовідносини держави з іншими іноземними державами тощо.

При оцінці внутрішньополітичного становища в регіоні чи державі, що вивчається необхідно акцентувати увагу на розподіл політичних сил та рівень стабільності політичної системи. Основні фактори: розподіл політичних сил; рівень стабільності політичної системи (найважливіше це існуючі розбіжності, в чому вони проявляються); ступінь соціальної активності основних класів та верств населення; ступінь впливу політичних партій, спілок, угруповань та громадських організацій на суспільно-політичні процеси в державі; наявність прихованої або відкритої опозиції до існуючої політичної влади, іiі активність і рівень впливу на населення (найважливіше це спрямованість, активність, лідери, кількість прибічників, у кого користується підтримкою, ступінь протистояння з владо тощо); формальні і тіньові лідери; роль ЗМІ в політичному житті держави; рівень міжнаціональних протиріч; мілітаризація держави; шовіністичні настрої суспільства; соціальна нерівність у розподілі прибутків; сепаратистські настрої; неузгодженість дій політичної влади до розв'язання політичних, економічних, соціальних проблем тощо.

Оцінка такого складника як, політичне (воєнно-політичне) керівництво включає до себе вивчення такої інформації: біографічні дані, рівень освіти, інтелектуальний потенціал, особливості характеру, вольові якості, захоплення, мотиваційна спрямованість на державні інтереси, зорієнтованість на загальновизнані моральні норми під час соціально-політичної діяльності, дотримання чинного законодавства, стилю керівництва, популярності, взаємостосунків в колективі, сім’є тощо.

Оцінка правових норм здійснюється за такими показниками: дієвість нормативно-правової бази, дієвість міжнародних та законодавчих актів з будь-яких питань врегулювань.

При оцінці політичної культури суспільства враховується наступні фактори: культура ставлення суб'єктів до політично влади, культура електорального процесу, культура формування політичних і громадсько-політичних інститутів, культура політичної поведінки, культура політичної свідомості й спілкування тощо.

Оцінка стану економіки регіону чи держави досліджується за наступними показниками: рівень економічного розвитку, темпи зростання виробництва, темпи падіння виробництва, стан науки і техніки, стан транспорту та зв'язку. Рівень розвитку фінансової системи, рівень підприємництва, наявність компетентних фахівців, наявність керівного складу, наявність кризових економічних ситуацій, середній рівень життя населення, частка державних витрат від валового національного 
продукту, частка відрахування коштів з держбюджету на соціальний захист населення, співвідношення між вартістю праці та її продуктивності, перспективний стан економіки, наявність важливих об'єктів промисловості, обсяг сільськогосподарського виробництва тощо.

Оцінка стану збройних сил здійснюється комплексно і цьому приділяється особлива увага. Аналіз нормативно-правової бази, керівні документи, сили та засоби інформаційно-психологічної боротьби, нетрадиційних засобів впливу тощо. Стан бойової готовності здійснюється за показниками: технічне оснащення, система та рівень комплектування збройних сил, соціальний та етнічний склад, морально-психологічна готовність особового складу, ступінь підготовленості за військово-професійними напрямками, ступінь володіння сучасними видами зброї, наявність бойового досвіду, віри в силу перемоги, ставлення цивільного населення до військовослужбовців, наявність антивоєнних настроїв, стан військової дисципліни, ступінь довіри до союзників, рівень розвитку воєнно-наукового прогресу, ступінь матеріального забезпечення військ, матеріальне становище військовослужбовців, ступінь впливу політичних партій і громадських організацій в армійському середовище, психологічна готовність військовослужбовців до початку військових дій тощо.

Важливим аспектом суспільно-політичної обстановки $є$ соціально-психологічна атмосфера в суспільстві. Основним показниками аналізу є: морально-психологічний стан населення, соціальна активність населення, ступінь психологічного дискомфорту в умовах економічної кризи, рівень соціальної взаємовідносин, ступінь рівноваги між класами населення, рівень занепокоєння населення, готовність до активних заходів (акцій протесту) населення, зони можливих зіткнень, підтримка державного порядку, ставлення до державних реформ, прагнення до контролю влади 3 боку населення, соціальний настрій, ставлення населення до зовнішньополітичного курсу, ставлення населення до союзницьких держав, ставлення населення до військовослужбовців, рівень пацифістських настроїв, зміст та динаміка розповсюдження інформації (відомостей) тощо.

Оцінка етноконфесійної ситуації залежить не тільки від місця та ролі церкви у житті суспільства, а від релігії середніх верств населення, наявності різних релігійних конфесій, характеристик спрямованості діяльності основних конфесій, характер стосунків органів державної влади та місцевого самоврядування, наявність різних представників різних релігійних конфесій, рівень міжрелігійного протиріччя, духовні, моральні, історичні цінності й ступінь їхньої єдності, місце знаходження культових релігійних споруд, негативні моменти віросповідання, традиції, звичаї, обряди, етнічні фактори тощо.

Оцінка демографічної ситуації висвітлюється потенціалами національних меншин, відтворення та міграція населення, чисельний та якісний склад, національний склад, наявність домінуючих національностей, місця компактного проживання національних меншин, рівень їх національної згуртованості, наявність національно-культурних товариств, взаємовідносини між представниками різних національностей i етнічних груп, наявність протиріччя, статевий склад, рівень освіти населення, формальні та неформальні лідери, впливові особи, віковий склад населення тощо.

Характеристика географічного середовища держави також висвітлюється за рахунок таких основних показників: розміри та заселення території, наявність корисних ресурсів, клімат, якість грунтів, наявність позитивної флори та фауни, річки та морський компонент, наявність або відсутність природних перешкод, розташування відносно союзницьких держав та противника, протяжність та стан кордону тощо.

При оцінці екологічної обстановки враховуються можливі зони екологічних проблем (відчуження), стан їх охорони, рівень забрудненості навколишнього середовища, тепловий фактор, радіоактивний фактор, наявність токсичних відходів та захоронень, позицію з боку інших держав тощо.

Оцінка криміногенної ситуації здійснюється, як правило, спільно із спеціальними органами за такими показниками: ступінь корумпованості вищого управлінського складу держави, злочинність у фінансовій сфері, наявність організованої злочинності, розповсюдження наркотиків, середній рівень тяжких злочинів, право та ступінь володіння вогнепальною зброєю під час скоєння злочинів, кількість незареєстрованої зброї у населення, ступінь контрабанди через кордон тощо.

Таким чином, потреба врахування всіх вищеперерахованих елементів той чи іншої обстановки суспільно-політичних процесів дозволяє зрозуміти необхідність аналізу, оцінки та прогнозування всіх факторів, умов, подій, процесів та явищ, які відбуваються, вже відбулися та будуть відбуватися у районі, що вивчається. 
Сьогодні, необхідність прогнозування майбутнього зумовлена як об'єктивними реаліями загальноцивілізаційного розвитку, так і проблемами більш конкретного, перспективного регулювання економічних, політичних i духовних, a також i військових відносин. Прогнозування має складний, міждисциплінарний характер, оскільки знаходиться на перетині політології, соціології, філософії, психології, історії, економічної теорії тощо. Аналіз сучасної наукової літератури, присвяченої проблемам прогнозування свідчить, що прогнозування це процес який висвітлює певний аспект, що створює методологічні передумови подальшої конкретизації дій [15]. Важливість прогнозування суспільно-політичної обстановки пов'язано 3 тим, що в сучасному суспільстві жоден соціальний інститут не може виникнути і утворитися поза тими відносинами, які складаються у політичній сфері. Прогнозування являє собою висновком про майбутнє політичного процесу, що досліджується, на основі загальної тенденції його розвитку. Предметом суспільно-політичного прогнозування $є$ сфера міждержавних та внутрішньодержавних відносин, внутрішньополітичні явища та інші чинники, що відносяться до суспільно-політичних процесів.

Розрізняють глобальне внутрішньополітичне і зовнішньополітичне прогнозування. Об'єктом глобального політичного прогнозування $є$ глобалізація у ії історичній динаміці- становленні єдиного взаємопов'язаного світу, в якому народи не відділені один від одного звичними протекціоністськими бар'єрами та кордонами, які одночасно і обмежують їх у спілкуванні і оберігають від невпорядкованих зовнішніх впливів. У сферу внутрішньополітичного прогнозування входить увесь зміст внутрішньої політики. При цьому існує два аспекти: перший пов'язаний із прогнозними оцінками конкретних політичних подій, другий - охоплює діяльність політичних інститутів суспільства. На основі зовнішньополітичного прогнозування оцінюється «загальна атмосфера» у світі, регіоні, країні, вивчаються тенденції, характер та напрямок розвитку, фактори які на них впливають, робляться спроби оцінити нові можливості розвитку. К. Сімонов об'єктом політичного прогнозу називає політичні системи та політичний процес [16].

Таким чином, під прогнозуванням в системі суспільно-політичних процесів слід розуміти імовірнісну, стохастичну за своїм характером, науково обгрунтовану думку про перспективи того чи іншого процесу або явища в майбутньому та про альтернативні шляхи і терміни його здійснення, на основі об'єктивності, системності, альтернативності, співмірності, та науковості. А це і є оцінка рівня та характеру суспільно-політичної обстановки, яка здійснюється з метою надання певної інформації вищому державному керівництву для прийняття обгрунтованого рішення. Відповідну схему аналізу, оцінювання та прогнозування суспільно-політичної обстановки в регіоні чи державі, що вивчається представлено на рисунку 1.

Суспільно-політичний процес завжди має динамічний характер і саме тому не може мати сталий рівень. Для визначення рівня суспільно-політичної обстановки необхідно всебічно і глибоко вивчити властивості і закономірності основних елементів змісту суспільно-політичної обстановки. До структурних елементів суспільно-політичної обстановки слід віднести не тільки діяльність суб'єктів суспільно-політичного процесу, а й соціально-політичні інтереси та цілі та реальні суспільно-політичні події, процеси, явища (рис. 2). Саме вплив таких чинників на суспільно-політичну обстановку буде визначати іï рівень, а саме: звичайна, загострена, кризова, надзвичайна.

Під звичайною суспільно-політичної обстановкою слід розуміти стабільний процес функціонування, стабільний процес взаємозв'язку суб'єктів суспільно-політичних відносин, відсутність соціального напруження.

Під загостреною (ускладненою) обстановкою слід розуміти ускладнені суспільно-політичні процеси. Зміст, структура і характерні особливості суспільно-політичних відносин між суб'єктами такі ж самі як і при звичайному рівні, але суспільно-політична атмосфера в якій здійснюється політичний процес - напружена.

Під кризовою обстановкою розуміють ситуацію у державі чи регіоні, яка склалася внаслідок протиправних i навмисних дій, пов'язаних з посяганням на нормальну, регулярну і безпечну діяльність суб'єктів суспільно-політичного процесу.

Надзвичайна суспільно-політична обстановка - порушення нормальних умов функціонування всіх процесів у державі чи окремому регіоні. Взаємовідносини суб'єктів суспільно-політичного процесу характеризується значним соціальним напруженням, яке загострилося настільки, що органи державної влади і місцевого самоврядування втратили контроль. 
Визначення та оцінювання потенційних факторів, умов, подій, процесів та явищ суспільно-політичного характеру(елементний склад):

- зовнішньополітичний курс країни;

- внутрішньополітична обстановка;

- політичне (воєнно-політичне) керівництво;

- оцінка політичних норм;

- аналіз політичної культури суспільства;

- стан економіки регіону чи країни;

- стан збройних сил (в тому числі аналіз можливостей ведення гібридної війни);

- соціально-психологічна атмосфера у суспільстві;

- етноконфесійна ситуація регіону чи країни;;

- демографічна ситуація регіону чи країни;

- географічне розташування;

- екологічна обстановка регіону чи країни;

- криміногенна ситуація регіону чи країни.

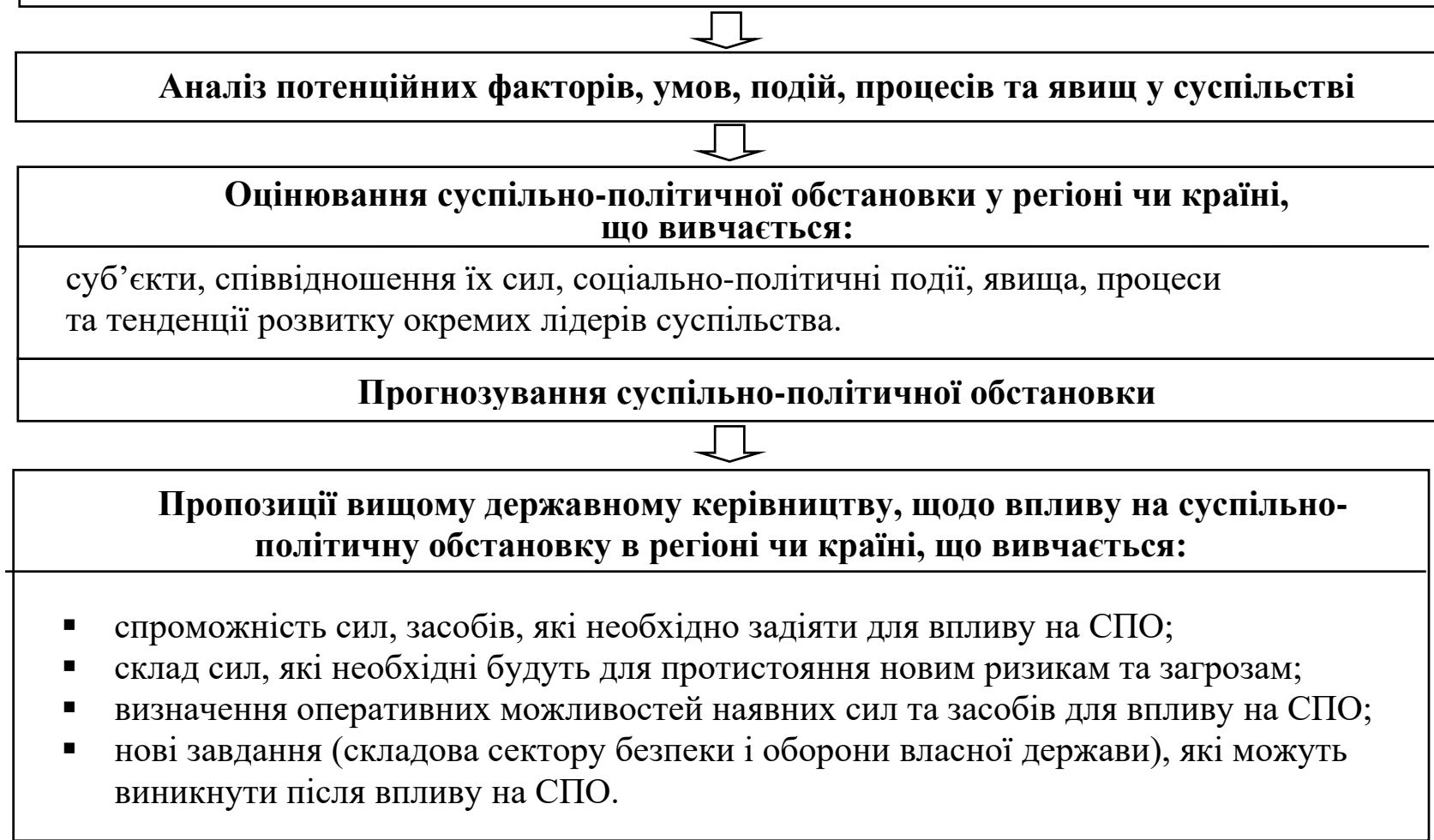

Рисунок 1. Схема аналізу, оцінювання та прогнозування суспільно-політичної обстановки в регіоні чи держсаві, че вивчається 
Основні структурні елементи змісту суспільно-політичної обстановки

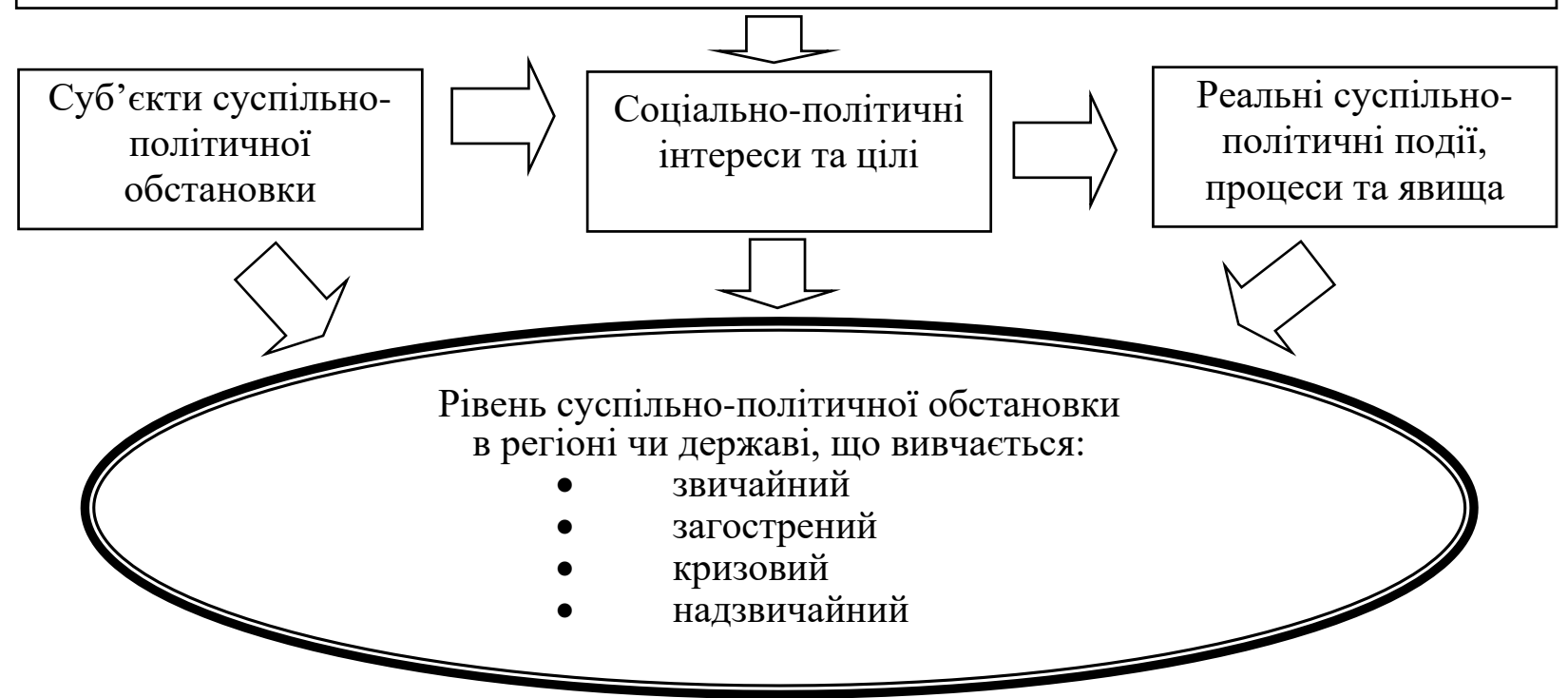

\section{Рисунок 2. Основні структурні елементи суспільно-політичної обстановки, щео визначають їі рівень}

Необхідно акцентувати увагу на тому, що суспільно-політична система будучи відкритою у своєму розвитку проходить перехідні етапи нестабільності, і успішний досвід використання тих чи інших підходів до становлення нової системи суспільних відносин не може гарантувати сталого функціонування суспільно-політичної системи у цілому.

I. Лиханова досліджує дві тенденції розвитку суспільно-політичної системи ${ }^{17}$. Вона пише, що в процесі свого існування соціальна система відчуває дві протилежні тенденції: з одного боку, це процеси дезорганізації, а з іншого - процеси самоорганізації і організації. Наростання внутрішніх проблем і протиріч робить суспільство несталим. Якщо суспільство перебуває у стані трансформації, суттєвої перебудови, то його несталий стан у певному розумінні неминучий. Якщо суспільство перетворюється, то воно не може бути стабільним в тій же мірі, як до цього.

Розгляд і узагальнення теоретичних підходів дозволяє зробити висновок, що головною метою оцінювання суспільно-політичної обстановки є відображення ситуації та визначення факторів, умов, подій, явищ, які необхідно постійно аналізувати для подальшого впливу на суспільно-політичні процеси. Для цього необхідно усвідомити зміст оцінювання суспільно-політичної обстановки, який елементний склад суспільно-політичної обстановки необхідно виокремлювати, яка послідовність аналізу факторів, що формують саме суспільно-політичну обстановку.

Таким чином, всебічний аналіз, оцінювання суспільно-політичної обстановки полягає у визначенні факторів розвитку та взаємовідносин суб'єктів суспільно-політичного процесу, які безпосередньо чи опосередковано впливають на діяльність суспільно-політичного процесу у державі чи окремому регіоні. Саме це надає керівництву держави можливість діяти щодо стабілізації, або дестабілізації ситуації, як на міжнародній арені, так і в середині держави.

\section{Бібліографічний список:}

1. Бусленко Н. П., Калашников В. В., Коваленко И. Н. Лекции по теории сложных систем. Москва: Советское радио, $1975.441 \mathrm{c}$.

2. Згуровский М. З., Панкратова Н. Д. Системный анализ. Проблемы, методология, приложения. Киев: Наукова думка, 2005. $743 \mathrm{c}$.

3. Згуровский М. 3. Исследование социальных процессов на основе методологии системного анализа / Згуровский М. З., Доброногов А. В., Померанцева Т. Н. Киев: Наукова думка, 1997. 221 с.

4. Блауберг И. В., Юдин Э. Г. Становление и сущность системного подхода. Москва: Наука, 1973. 274 с.

5. Щедровицкий Г. П. Проблемы методологии системного исследования. Москва: Машиностроение, 1954. 279 c. 
6. Тимченко А. А. Системний підхід до наукового дослідження (методико-технологічні аспекти) / А. А. Тимченко // Вісник ЧДТУ. - 2005. - № 1. - С. 191-197.

7. Плют В. Сравнительный многомерный анализ в экономических исследованиях: Методы таксономии и факторного анализа / Плют В. Москва: Статистика, 1980. 151 с.

8. Литвак Б. Г. Экспертная информация: Методы получения и анализа / Литвак Б. Г. Москва: Радио и связь, 1984. С. 118.

9. Китаев Н. Н. Групповые экспертные оценки / Китаев Н. Н. Москва: Экономика, 1975. С. 64.

10. Бешелев С. Д. Математико-статистические методы экспертных оценок / С. Д. Бешелев, Ф. Г. Гурвич. Москва: Статистика, 1980. 263 с.

11. Волошин О. Ф. Моделі та методи прийняття рішень / О. Ф. Волошин, С. О. Мащенко. [2-ге вид., перероб. та допов]. Київ: Видавничо-поліграфічний центр «Київський університет», 2010. 336 с.

12. Снитюк В. Е. Эволюционные технологии принятия решений в условиях неопределенности: монография / Снитюк В. Е. Київ: «МП Леся», 2015. 347 с.

13. Снитюк В. С. Прогнозування. Моделі, методи, алгоритми / В. С. Снитюк. Київ: Маклаут, 2008. 364 с.

14. Згуровський М. 3. Сценарний аналіз як системна методологія передбачення / М. З. Згуровський // Системні дослідження та інформаційні технології. 2002. № 1. С. 7-38.

15. Азаров I. Підготовка майбутніх офіцерів до прогностичної діяльності у процесі навчання у вищих військових навчальних закладах: дис. ... канд. пед. наук: 13.00.04 / Нац. ун-т оборони України ім. Івана Черняховського. Київ, 2018. С. 64.

16. Симонов К. В. Политический аналіз : учеб. пособие / К. В. Симонов. Москва: Логос, 2002.152 с. С. 44.

17. Лиханова И. В. Дестабилизирующие факторы политического процесса и национальная безопасность: современный теоретический дискурс // Вестник Московского университета. Серия 12. Политические науки. 2004. № 3. С. 59, 60.

\section{References:}

1. Buslenko N. P., Kalashnikov V. V., Kovalenko I. N. Lektsii po teorii slozhnyih sistem. Moskva: Sovetskoe radio, $1975.441 \mathrm{p}$.

2. Zgurovskiy M. Z., Pankratova N. D. Sistemnyiy analiz. Problemyi, metodologiya, prilozheniya. Kiev: Naukova dumka, 2005. 743 p.

3. Zgurovskiy M. Z. Issledovanie sotsialnyih protsessov na osnove metodologii sistemnogo analiza / Zgurovskiy M. Z., Dobronogov A. V., Pomerantseva T. N. Kiev: Naukova dumka, 1997. 221 p.

4. Blauberg I. V., Yudin E. G. Stanovlenie i suschnost sistemnogo podhoda. Moskva: Nauka, 1973. 274 p.

5. Schedrovitskiy G. P. Problemyi metodologii sistemnogo issledovaniya. Moskva: Mashinostroenie, 1954. 279 p.

6. Timchenko A. A. Sistemniy pIdhId do naukovogo doslIdzhennya (metodiko-tehnologIchnI aspekti)

/ A. A. Timchenko // VIsnik ChDTU. 2005. - № 1. P. 191-197.

7. Plyut V. Sravnitelnyiy mnogomernyiy analiz v ekonomicheskih issledovaniyah: Metodyi taksonomii i faktornogo analiza / Plyut V. Moskva: Statistika, 1980. 151 p.

8. Litvak B. G. Ekspertnaya informatsiya: Metodyi polucheniya i analiza / Litvak B. G. Moskva: Radio i svyaz, 1984. P. 118.

9. Kitaev N. N. Gruppovyie ekspertnyie otsenki / Kitaev N. N. Moskva: Ekonomika, 1975. P. 64.

10. Beshelev S. D. Matematiko-statisticheskie metodyi ekspertnyih otsenok / S. D. Beshelev, F. G. Gurvich. Moskva: Statistika, 1980. 263 p.

11. Voloshin O. F. ModelI ta metodi priynyattya rIshen / O. F. Voloshin, S. O. Maschenko. [2-ge vid., pererob. Ta dopov]. KiYiv: Vidavnicho-polIgrafIchniy tsentr «KiYivskiy unIversitet», 2010. 336 p.

12. Snityuk V. E. Evolyutsionnyie tehnologii prinyatiya resheniy v usloviyah neopredelennosti: monografiya / Snityuk V. E. KiYiv: «MP Lesya», 2015. 347 p.

13. Snityuk V. E. Prognozuvannya. ModelI, metodi, algoritmi / V. E. Snityuk. KiYiv: Maklaut, 2008. 364 p.

14. Zgurovskiy M. Z. Stsenarniy analIz yak sistemna metodologIya peredbachennya / M. Z. Zgurovskiy // SistemnI dosIIdzhennya ta InformatsIynI tehnologIYi. 2002. \# 1. P. 7-38.

15. Azarov I. PIdgotovka maybutnIh ofItserIv do prognostichnoYi dIyalnostI u protsesI navchannya u vischih vIyskovih navchalnih zakladah: dis. ... kand. ped. nauk: 13.00.04 / Nats. un-t oboroni UkraYini Im. Ivana Chernyahovskogo. KiYiv, 2018. P. 64.

16. Simonov K. V. Politicheskiy analIz : ucheb. posobie / K. V. Simonov. Moskva: Logos, 2002.152 p. P. 44.

17. Lihanova I. V. Destabiliziruyuschie faktoryi politicheskogo protsessa i natsionalnaya bezopasnost: sovremennyiy teoreticheskiy diskurs // Vestnik Moskovskogo universiteta. Seriya 12. Politicheskie nauki. 2004. \# 3. P. 59, 60 .

\section{Semenyuk Y. V., Holynskyi I. M. Identification and justification of essential components of social and political situation}

Systems analysis is a generally accepted methodology used to study complex social and economic as well as technical systems. Based on essential provisions and methods of systems analysis it has been discovered that composition of elements of social and political situation has to include information 
on studied sphere or process of the state or region. Not only passive reflection of information on events or identification of a certain process, but also trends of situation development and real capabilities of political powers and institutions as well as orientations and capabilities of governing elite are among essential elements of the social and political situation. Thus, to have a systemic assessment of social and political situation in certain state or region there should be analysed its following elements: foreign policy; political situation in region or state; political (military and political) leadership; political norms assessment; analysis of political culture of society; economical situation in the state or region; armed forces state (including capacity to run hybrid wars); social and psychological environment in the society; ethno-confessional situation in the region or state; demographic situation in the region or state; geographic location; ecological situation in the region or state; criminal situation in the region or state. Thus, the need to take into account all above elements of a certain situation of social and political processes leads to understanding the need for analysis, assessment and forecasting of all factors, conditions, events, processes and phenomena that took place, are taking place or will take place in the studied region.

Today the need to forecast the future is determined by both objective realities of the general civilizational development and problems of specific perspective regulation of economic, political, spiritual and military relations. Forecasting has complex interdisciplinary nature formed on the crossroad of political science, sociology, philosophy, psychology, history, economical theory etc. Analysis of contemporary scientific literature devoted to forecasting proves that it is the process shedding light on a certain aspect creating methodological preconditions for further specification of actions.

Thus, the forecasting in the system of social and political process is a probabilistic, stochastic and scientifically justified opinion on perspectives of a certain processes or phenomenon in future and alternative ways and terms of its realization on the basis of objectivity, proportionality as well as alternative, systemic and scientific approaches.

Social and political process always has dynamic nature so it can never be static. To identify the level of social and political situation a comprehensive and deep study of features and patterns of essential elements of social and political situation is required. There are not only actions of social and political process agents but also social and political interests and goals as well as real social and political events, processes and phenomena among structural elements of social and political situation. Their impact on social and political situation will define its level: normal, critical, emergent.

Study and generalization of theoretical approached leads to a conclusion that main goal of social and political situation assessment is the reflection of situation and identification of factors, conditions, events, phenomena that require constant analysis for further impact on social and political processes. It requires realization of the essence of social and political situation assessment as well as its elements that need identification. There should also be defined the sequence of analysis of factors that create social and political situation.

Thus, the comprehensive analysis and assessment of social and political situation provides for identification of factors of development and mutual relation of the agents of social and political process, which have direct or indirect impact on social and political process in the state or separate regions. This is exactly what enables the state administration take actions for stabilization or destabilization of situation both in the international arena or locally.

Key words: social and political situation, element composition, social and political process, assessment, forecasting, factors, conditions, events, phenomena. 